Cornell Law Library

Scholarship@Cornell Law: A Digital Repository

Cornell Law Faculty Publications

Faculty Scholarship

$5-1995$

\title{
Developing Countries and Multilateral Trade Agreements: Law and the Promise of Development
}

Chantal Thomas

Cornell Law School, chantal-thomas@lawschool.cornell.edu

Follow this and additional works at: http://scholarship.law.cornell.edu/facpub

Part of the International Law Commons, International Trade Commons, and the Jurisprudence Commons

\section{Recommended Citation}

Thomas, Chantal, "Developing Countries and Multilateral Trade Agreements: Law and the Promise of Development" (1995). Cornell Law Faculty Publications. Paper 1100.

http://scholarship.law.cornell.edu/facpub/1100

This Article is brought to you for free and open access by the Faculty Scholarship at Scholarship@Cornell Law: A Digital Repository. It has been accepted for inclusion in Cornell Law Faculty Publications by an authorized administrator of Scholarship@Cornell Law: A Digital Repository. For more information, please contact jmp8@cornell.edu. 


\section{DEVELOPING COUNTRIES AND MULTILATERAL TRADE AGREEMENTS: LAW AND THE PROMISE OF DEVELOPMENT}

The Uruguay Round, finalized on April 15, I994, ${ }^{1}$ by the contracting parties to the General Agreement on Tariffs and Trade (GATT), ${ }^{2}$ promises to constitute "the largest, most comprehensive trade agreement in history." 3 Some commentators believe the Round evidences the progression of international law toward a global parallel with domestic legal systems. ${ }^{4}$ At the same time, other commentators have voiced skepticism about the legal and practical significance of the new GATT rules. ${ }^{5}$ In particular, the repeated disappointments that multilateral trade agreements have brought developing countries (DCs) cause some commentators to doubt the degree to which the Uruguay Round will improve prospects for these countries. ${ }^{6}$ This Note exam-

1 See Final Act Embodying the Results of the Uruguay Round of Multilateral Trade Negotiations, Apr. 15, I994, 33 I.L.M. II43. The "Results" of the Uruguay Round include the "Agreement Establishing the World Trade Organization," which includes all Multilateral Trade Agreements, the "Ministerial Declarations and Decisions," and the "Understanding on Commitments in Financial Services." See id. The Uruguay Round was launched in I986 by the Punta del Este Ministerial Declaration. See Ministerial Declaration on the Uruguay Round (Sept. 20, 1986), in General Agreement on Tariffs and Trade, Bastc InSTRUMents and Selected Documents ig (33d Supp. 1987) [hereinafter Punta del Este Ministerial Declaration].

2 General Agreement on Tariffs and Trade, Oct. 30, I947, 6I Stat. A3 (pts. 5 \& 6), 55 U.N.T.S. I88 [hereinafter GATT].

${ }^{3}$ Results of the Uruguay Round Trade Negotiations: Hearings Before the Senate Comm. on Finance, ro3d Cong., 2d Sess. 2II (I994) (statement of U.S. Trade Representative Mickey Kantor). The Uruguay Round extends the GATT's liberalizing scope to previously excluded areas (such as services, intellectual property, and textiles). See Agreement Establishing the World Trade Organization, Apr. 15, I994, Annex IB, art. II, 33 I.L.M. II44, II69 [hereinafter WTO Agreement] (applying most-favored-nation treatment to services); id. Annex IC, arts. 3, 4, at II99-I200 (extending national treatment and most-favored-nation treatment to intellectual property); Agreement Establishing the World Trade Organization, Apr. 15, 1994, Annex IA, reprinted in TraDE NEgotiations Comm., Final ACt EMbodying the Results of THE URUGUAY Round of the Multilateral Trade Negotiations 21, 86-9I [hereinafter Final ACT] (setting forth provisions for the integration of textiles into the GATT). The Round also strengthens rules pertaining to areas previously only partially addressed (such as agriculture), see id., reprinted in FINAL ACT, supra, at 45. The Agreement also establishes the World Trade Organization (WTO) in order to improve compliance with GATT obligations. See WTO Agreement, supra, at II44-52 (describing the WTO's administrative and enforcement structures and operation).

4 See, e.g., Kenneth W. Abbott, GATT as a Public Institution: The Uruguay Round and Beyond, I8 BROOK. J. INT'L L. 3r, 43-84 (I992) (reviewing the institutional progress achieved by the Uruguay Round and making suggestions for further strengthening of the GATT trade system).

5 See, e.g., J. Michael Finger, That Old GATT Magic No More Casts Its Spell (How the Uruguay Round Failed), 25 J. WORLD TRADE 19, 20 (r991); Jarl Hagelstam, Mercantilism Still Infiuences Practical Trade Policy at the End of the Twentieth Century, 25 J. WORLD TRADE 95, 96-I05 (1991); James M. Lutz, GATT Reform or Regime Maintenance: Differing Solutions to World Trade Problems, 25 J. WORLd TRADE IO7, II2-I5 (I99I).

6 See, e.g., Bartram S. Brown, Developing Countries in the International Trade Order, $\mathrm{I}_{4} \mathrm{~N}$. IIL. U. L. REV. 347, 37I-79 (1994); Michael Rom, Some Early Reflections on the Uruguay Round as Seen from the Viewpoint of a Developing Country, 28 J. WORLD TRADE 5, 29-30 (1994); $c f$. 
ines the reasons for those disappointments and considers whether the Uruguay Round Agreement can overcome them.

In evaluating the import of the Uruguay Round to DCs, this Note adopts a theoretical perspective. A century-old stalemate between utopian (or progressionist) ${ }^{7}$ and cynical (or realist) ${ }^{8}$ views of international law, however, has caused international legal theorists to declare their discipline in crisis." In recent years, a "New Stream" of (post)modern theorists has attempted to wrest international legal discourse away from these warring sides. ${ }^{10} \mathrm{New}$ Stream theorists consider the utopian imperative to construct a supranational government outdated, ${ }^{11}$ but they are also reluctant to concede everything to politics. ${ }^{12}$ Although New Stream thinkers offer no cohesive theory, they agree on the necessity of abandoning the insistence either on privileging one side of the dichotomy over the other, or on falsely reconciling them. ${ }^{13}$

This Note will suggest that New Stream efforts should not altogether dismiss the traditional dichotomy between utopian and cynical perspectives. The tension between these perspectives, though theoretically inelegant, still offers important explanatory and predictive insight, at least with respect to North-South international trade relations. Because progressionist and realist world views - hopelessly contradictory as they may be - seem to shape the language and interactions of state governments, formulating alternative conceptualizations of international law may serve simply to obscure, rather than to further, effective strategies by DCs. This Note prescribes neither a return to the struggle of the traditional dichotomy nor a reconciliation of opposing camps; rather, it advocates embracing the dichotomy both as an identification of competing state strategies in international legal interac-

B.L. Das, Introduction to United Nations, Uruguay Round: Further Papers on Selected IssuEs at xiii, xiii-xv (1990) (noting the need to study and resolve potential flaws in the Uruguay Round negotiations).

7 See infra note $I_{5}$ and accompanying text.

8 See infra note 64.

9 See Martti Koskennem, From Apoplogy to Utopia: The Structure of Interna. tional Legal ARgument 460-64 (rg89); Richard A. Falk, The Relevance of Political Context to the Nature and Functioning of International Law: An Intermediate View, in THE RELEVANCE of International LAW r33, I33 (Karl W. Deutsch \& Stanley Hoffmann eds., I968); David Kennedy, Theses About International Law Discourse, 23 GERMAN Y.B. INT'L L. 353, 390 (1980).

10 Professor David Kennedy has bibliographed the development of these contemporary critical projects, identifying them as a "New Stream." See David Kennedy, A New Stream of International Law Scholarship, 7 Wis. INT'L L.J. 1, 47-49 (1988); David Kennedy \& Chris Tennant, New Approaches to International Law: A Bibliography, 35 HARV. INT'L L.J. 417, 431-60 (1994). For examples of New Stream scholarship, see KoskENNIEMI, cited above in note 9; Anthony Carty, Critical International Law: Recent Trends in the Theory of International Law, 2 EUR. J. INT'L L. 66 (I99I); and Kennedy, cited above in note 9.

11 See, e.g., Marti Koskenniemi, The Politics of International Law, 1 EUR. J. INT'L L. 4, 9 (I990).

12 See Kennedy, supra note 9, at 357-58.

13 See infra p. 1729-30. 
tions and as a recognition of competing futures in international law. This reconceptualization explains seemingly contradictory state actions and prescribes strategies for DCs with regard to multilateral trade agreements, including those resulting from the Uruguary Round.

Part I will recount the theoretical crisis in the context of international trade law by surveying its history according to both the legalistic, progressionist view and the politicizing, cynical approach. The survey relating the progressionist view will summarize the history of DCs' efforts to utilize legal rules and processes - by reforming the GATT and by founding the United Nations Conference on Trade and Development (UNCTAD) - to restructure their positions in international trade. The survey employing the cynical approach will retrace that history with an eye to the respective failures of the two trade regimes to establish law as "an autonomous dimension in international life."14 Part II will reflect on international legal theory and will conclude that discarding the traditional dichotomy may unduly discount its explanatory and prescriptive value, especially for DCs involved in current international trade relations. In recovering this dichotomy, Part II notes alternative futures in international trade relations between DCs and industrialized countries (ICs) and counsels DCs to strategize with both in mind.

\section{A Twice-Told Tale of International Trade Law}

\section{A. International Trade Law as an Evolution Toward Legality}

Progressionist or utopian international legal theory views international law as slowly inching toward greater institutionalization and authority. ${ }^{15}$ A progressionist history of contemporary international trade law might begin after World War II, when the United States called for a multilateral organization that would work toward the liberalization of domestic and international trade. ${ }^{16}$ The International Trade Organ-

14 Falk, supra note 9, at $\mathrm{I} 33$.

15 See, e.g., Richard Fat, Revitalizing International Law passim (Ig8g); T.J. LawRENCE, Is There a True International Law?, in Essays on SOME Disputed QUESTIONS IN MODern International LaW I, I-16, 22-23 (Cambridge, Deighton, Bell \& Co., 2d ed. 1885) (constructing a theory basing international law's legitimacy on "order" rather than "force"). A more subtle progressionism informs "reconstructivist" scholarship, which argues that the current weaknesses in international law are exaggerated. See, e.g., LoUIS HENkIN, How NATIONS BEHAVE 4I-42 ( $\mathrm{I} 968$ ) (characterizing "the common impression that the field of international law is sown with violated norms and broken treaties" as "grossly mistaken" and noting that "[i]t is probably the case that almost all nations observe almost all principles of international law ... almost all of the time"); Thomas M. Franck, Legitimacy in the International System, 82 AM. J. INT'L L. 705, 710 (I988) (asserting that "many rules are obeyed much of the time").

16 See Joan E. Spero, The Politics of International Economic Relations 69 (4th ed. I990). This initiative formed part of the U.S. effort to rebuild the world according to the theory that market-driven capitalism would spread prosperity and help to ensure peace. See E.F. PENROSE, Economic PlanNming for the PEACE 3 (1953). The United States also believed that, as 
ization (ITO) which resulted from these efforts perished before reaching fruition. ${ }^{17}$ However, the General Agreement on Tariffs and Trade, a skeletal interim agreement "drawn up in 1947 to provide a procedural base and establish guiding principles" for the ITO negotiations, survived as the unlikely but only successor to the enterprise of organized world trade. ${ }^{18}$

The GATT's vision of global market-led prosperity was rooted in a belief that liberalization of domestic and international trade barriers would encourage trade to develop according to the principle of comparative advantage, maximizing the efficiency and the growth of international economic activity. ${ }^{19}$ However, the GATT also incorporated other principles into its free trade ideal. In its principle of nondiscrimination, the GATT recognized the importance of ensuring equitable trade by mandating that contracting parties treat imports and exports of all contracting parties identically. ${ }^{20}$ In its principle of reciprocity, the GATT retained a current of protectionism by requiring contracting parties seeking tariff concessions from other parties to offer concessions of reciprocal value. Together, the notions of liberalization, nondiscrimination, and reciprocity informed the overarching rule of most-favorednation (MFN) treatment: nations must treat all like products "originating in or destined for" other member nations alike. ${ }^{21}$

The post-World War II independence of most African, Caribbean, and Pacific colonies set the stage for international trade relations between DCs and ICs. In pursuit of economic growth, many DCs joined the GATT, so that within two decades DCs had grown from fewer than half to two-thirds of the GATT's contracting parties. ${ }^{22}$ As their numbers increased during the I960s and I970s, DCs produced "Third World" critiques of the global status quo, ${ }^{23}$ often centered on the theory that structural characteristics of the international economy calcified the dependence of DCs on ICs. ${ }^{24}$ Although the GATT had

the dominant world economy, it had "the most to gain from an open world market for exports." Robert E. Hudec, Developing Countries in the GATT Legal System Io (I987).

17 See SPERO, supra note 16 , at 68-69 (briefly recounting the ITO's history).

18 Id. at 70.

19 See John H. Jackson, Worid Trade and the LaW of GaTT $33^{\circ}$ (x969).

20. See GATT, supra note 2, art. XIII, 6I Stat. at $A_{40}-A_{43}, 55$ U.N.T.S. at 234-39. The corollary principle of national treatment prohibits contracting parties from domestically regulating the products of other contracting parties less favorably than their own products. See id. art. II, 6I Stat. at AI4-AI7, 55 U.N.T.S. at 196-200.

21 GATT, supra note 2, art. I, II I, 6I Stat. at AI2, 55 U.N.T.S. at I92.

22 See HudEc, supro note 16 , at 23-24. After two more decades, DCs comprised almost three-quarters of the GATT's contracting parties. See id.

23 For a sample of this discourse, see the essays in Beyond Dependency: The Developing World Speaks Out (Guy F. Erb \& Valeriana Kallab eds., 1975). See also Linus A. Hoskins, The New International Economic ORDER: A BibliographIC HaNDBOoK (I982) (summarizing and bibliographing the literature).

24 The vast writing on this subject can be loosely divided between radical and reformist arguments. For an example of the former viewpoint, see ANDre G. Frank, Capitalism and UN- 
promised market-led growth to those countries willing to reduce trade restrictions, DCs found that their export earnings were declining. ${ }^{25}$ DCs thus lodged demands for differential treatment under the GATT that would reflect their lesser economic capacity. ${ }^{26}$ Even though a GATT investigation substantiated many of the DCs' claims and called for their increased access to ICs' markets, ${ }^{27}$ the GATT delayed acting decisively on these findings. ${ }^{28}$

Thus, as the I960s began, DCs turned to the United Nations as an alternative mechanism through which to effect international legal change and, by I964, succeeded in organizing a Conference on Trade and Development (UNCTAD). ${ }^{29}$ UNCTAD served as a forum in which DCs could fully express their grievances regarding the prevailing international economic structure. ${ }^{30}$ Moreover, DCs employed their numerical advantage to establish principles and programs intended to transform that structure into what they perceived as a more equitable world order. ${ }^{31}$ UNCTAD argued for, among a wide range of other concerns, the improvement of the terms of international trade in primary products, the DCs' main exports, ${ }^{32}$ and urged the "removal of obstacles and discriminatory practices used to protect domestic agriculture and processing industries in the North." ${ }^{\text {33 }}$ In addition, for the first time DCs forcefully articulated demands for non-reciprocal trade

DERDEVELOPMENT IN LATIN AMERICA IIg-20 (Ig6g). For an example of the latter approach, see United Nations Conference on Trade and Dev., United Nations, Towards a New Trade Policy for Development ir (ig64) [hereinafter Towards a New Trade Policy], a work authored by Raúl Prebisch, as UNCTAD Secretary-General).

25 See HUDEc, supra note 16 , at 44-45.

26 These efforts resulted in documents such as the Programme of Action Directed Towards An Expansion of International Trade (Nov. I7, 1958), in GENERAL AGREEMENT ON TARIFfS AND Trade, Basic Instruments AND SELEcted Documents 27 (7th Supp. 1959) and Impact of Commodity Problems on International Trade, GATT Doc. I/IIo3 (Nov. 20, 1959), in GENERAL Agreement on Tariffs and Trade, Basic Instruments and Selected Documents 76 (8th Supp. I960).

27 See General agreement on Tariffs and Trade, Trends in International Trade: Report By A PANEL OF ExPERTS 80-95 (I958) (commonly known as the "Haberler Report").

28 Instead, GATT periodically issued statements supporting, but not implementing unilateral trade concessions to DCs as a means of facilitating development. See HuDEC, supra note r6, at 44-45. For examples of such statements see the sources cited above in note 26 .

29 See Branislav Gosovic, UNCTAD: CoNflict aNd CoMpromise 15-16 (r972).

30 See id. at $\mathrm{x}$; Isebill V. Gruhn, The New International Economic Order and the United Nations, in The Future of Africa AND THE NEW InTERnational Economic ORDER 42, 44-45 (Ralph I. Onwuka \& Olajide Aluko eds., 1986).

31 See, e.g., Brown, supra note 6, at 36I-62. As discussed below, the numerical clout of DCs was diffused within the GATT structure. See infra p. 1726.

32 See United Nations Conference on Trade and Dev., United Nations, The HisTORY OF UNCTAD 1964-1984, at 9 (1985) [hereinafter THE HisTORY OF UNCTAD]; TOWARDS a New Trade Policy, supra note 24 , at II.

33 Gosovic, supra note 29 , at 30 . 
preferences $^{34}$ at "fair and remunerative levels."35 Finally, the DCs called for "[i]mprovement of institutional arrangements, including if necessary, the establishment of new machinery and methods for implementing the decisions of the Conference."36

Having entered a period of relative economic vulnerability, ${ }^{37}$ ICs began to respond more substantially to DCs' demands. In I965, the GATT contracting parties added to the Agreement a "Part IV" entitled "Trade and Development." 38 Although Part IV endorsed differential treatment of DCs more forcefully than did Article XVIII, ${ }^{39}$ it stopped short of legally binding the contracting parties to accomplish its directives. ${ }^{40}$ Nonetheless, the addition reaffirmed the DCs' status as a numerical majority bloc that could gain legal reform in the GATT and UNCTAD. Over the next several years, trends in international economic relations introduced a period of unusual Southern strength, ${ }^{41}$ thereby presenting DCs with further opportunities to apply this technique. DCs seized this historical moment to secure changes in the GATT and to establish programs through UNCTAD that reflected their agenda for international economic reform. ${ }^{42}$

Somewhat persuaded that Northern dependence on the South was permanently increasing, the ICs began to fear, particularly in the wake of OPEC and other cartels, that the South might break away from the GATT altogether, and thus, began to work more cooperatively with

34 See THE History OF UNCTAD, supra note 32, at 107.

35 Joint Declaration of the Developing Countries, annexed to G.A. Res. 1897, U.N. GAOR, I8th Sess., Annex I, Agenda Items 12, 33-37, $39 \& 76$, at 65, annex at 66 (1963).

36 Id.

37 As the European and Japanese economies recovered and began to participate more fully in international trade, the American policy of maintaining balance-of-payment deficits in order to supply currency to the international market weakened the dollar and increased American vulnerability to swings in international trade and investment. See SPERo, supra note 16, at 36-45.

38 Protocol Amending the General Agreement on Tariffs and Trade to Introduce a Part IV on Trade and Development, Feb. 8, I965, I7 U.S.T. 1977, 572 U.N.T.S. 320 [hereinafter Part IV].

39 For a discussion of Article XVIII, see page I724 below.

40 See Part IV, supra note 38 , arts. XXXVI, XXXVII, I7 U.S.T. at $1978-83,572$ U.N.T.S. at 322-29. Part IV juxtaposed seemingly commanding uses of the word "shall" with numerous exceptions that rendered it no more than an "agreed statement of principle." HUDEC, supra note 16, at 57-58. "From a technical point of view, Part IV added nothing to the existing legal relationship between developed and developing countries" but was rather "merely a slightly more impressive statement of the urgent but non-binding" statements about unilateral concessions the GATT had been issuing for some time. Id. at 56 .

41 See supra note 37 . Northern economic hegemony was destabilized in the early 19705, when the Organization of Petroleum Exporting Countries (OPEC) exploited a global oil shortage to begin controlling oil prices unilaterally. See generally ZUHAYR MIKDASH, THE CommUNITY of OIL EXPORTING COUNTrIES 69-94, 157-95 (1972) (analyzing the development of cooperation between OPEC countries and their success in controlling oil prices). Moreover, as Northern economic consumption increased, Northern supplies of raw materials decreased, and Northern economic actors increasingly sought raw materials produced by the South.

42 See generally UNCTAD aND THE NoRTh-South Dialogue 10-32 (M. Zammit Cutajar ed., 1985) (cataloging achievements of the DCs in the 1970s). 
DCs to implement their demands. ${ }^{43}$ In I97 I, the GATT adopted a General System of Preferences (GSP), which allowed ICs to waive their right to reciprocity from DCs and extend concessions unilaterally. ${ }^{44}$ Emboldened, the South intensified its pressure for change in North-South international economic relations. In I974, the United Nations General Assembly announced the "Establishment of a New International Economic Order." 45 The General Assembly also created a Charter of Economic Rights and Duties of States, ${ }^{46}$ which sought to "establish generally accepted norms to govern international economic relations" on a "just and equitable basis."47 From I974 to I976, DCs continued to work for reforms in market access and stability that they believed would encourage their "active, full and equal participation" in the international economic order. ${ }^{48}$

However, as the r97os progressed, Southern unity began to disintegrate. Declining commodities prices, Northern substitution of synthetic products for DC exports, and competition between DC exporters gradually eroded the relative economic strength of DCs. ${ }^{49}$ The GATT Tokyo Round largely disfavored $\mathrm{DCs},{ }^{50}$ and many UNCTAD reform mechanisms foundered.51 Escalating debt also substantially weakened

43 See SPERO, supra note 16, at $212-14$.

44 See Generalized System of Preferences, GATT Doc. L/3545 (June 25, I971), in GENERAL agreement on Tariffs and Trade, Basic Instruments and Selected Documents 24, 25-26 (18th Supp. 1972). See generally Ndiva Kofele-Kale, The Principle of Preferential Treatment in the Law of GATT: Toward Achieving the Objective of an Equitable World Trading System, 18 CAL. W. INT'L L.J. 29I, 299-304 (1988) (describing the GSP).

45 Declaration on the Establishment of a New International Economic Order, G.A. Res. 3201 , U.N. GAOR, 6th Special Sess., Supp. No. I, at 3, 3, U.N. Doc. A/9559 (I974); Programme of Action on the Establishment of a New International Economic Order, G.A. Res. 3202, U.N. GAOR, 6th Special Sess., Supp. No. I, at 5, U.N. Doc. A/9559 (1974). The Declaration proclaimed:

The present international economic order is in direct conflict with current developments in international political and economic relations. . . . The developing world has become a powerful factor that makes its influence felt in all fields of international activity. These irreversible changes in the relationship of forces in the world necessitate the active, full and equal participation of the developing countries in the formulation and application of all decisions that concern the international community.

G.A. Res. 320I, supra, at 3 .

46 G.A. Res. 328I, U.N. GAOR, 29th Sess., Supp. No. 3I, at 50, U.N. Doc. A/g63I (I974).

47 Id. The Charter set out rights and obligations that developed the principles set forth in the Declaration. See id. at 50-55.

48 G.A. Res. 3201, supra note 45, at 3. See generally Branislav Gosovic \& John G. Ruggie, On the Creation of a New International Economic Order: Issue Linkage in the Seventh Special Session of the UN General Assembly, 30 INT'L ORG. 309, 310-44 (I976) (tracing the strategies advanced by DCs in pursuit of a "new international economic order").

49 See SPERO, supra note I6, at 214-15.

50 See Unted Nations Conference on Trade and Dev., United Nations, Assessment of the Results of the Multilateral Trade Negotiations 7 (I982). The Tokyo Round's impact on developing countries is discussed further in notes 76-77 below and accompanying text.

51 See SPERO, supra note 16, at 214-15. 
the DCs' position.52 Thus, at the beginning of the I980s, the DCs, with few exceptions, faced economic obstacles as grave as those they had faced a quarter-century earlier at the dawn of their entry into the international arena as politically independent entities..$^{\mathbf{5 3}}$

Despite these setbacks, DCs continued to press for reform in international trade law. ${ }^{54}$ The GATT Ministerial Declaration announcing the Uruguay Round of multilateral negotiations in 1986 incorporated many of these concerns.55 The Declaration resolved that the negotiations would achieve "further liberalization and expansion of world trade to the benefit of all countries, especially less-developed contracting parties, $\$ 56$ and placed special emphasis on the need for negotiations in tropical products, textiles and agriculture - industries historically of concern to the DCs. ${ }^{57}$ The Final Act of the Uruguay Round has, in some measure, succeeded in fulfilling these initial exhortations. ${ }^{58}$ The Round seeks to improve both the coherence of the GATT's substantive trade obligations and the authoritativeness of those obligations. With respect to the first issue, the Round both expands and strengthens trade liberalizations in industries, such as agriculture, ${ }^{59}$ that the GATT had previously addressed only minimally. The Round also establishes liberalizing obligations in several areas previously unaddressed, including textiles, intellectual property, and trade in services. ${ }^{60}$

In addition to its attempts to fortify the GATT's substantive rule structure, the Uruguay Round also seeks to increase the GATT's authoritativeness. The World Trade Organization (WTO), an institution established to administer and adjudicate GATT obligations, forms the

52 See id. at 196.

53 See Dale Furnish, Paul D. Reynolds, Stephen T. Zamora \& John F. Dorsey, Trade and Finance Prospects for the Developing Nations in the r980s, 76 PROc. AM. Soc'Y INT'L L. 206, 2I5 (I982); Gregory O. Lunt, Graduation and the GATT: The Problem of the NICs, 3 I Colum. J. TRANSNAT'L L. 6II, 6II-I2 \& n.II (I994); cf. B.K. Agnihotri, Critical Issues Facing International Economic Order, Io S.U. L. REv. I, 3 (I983) (noting the "frustration" of DCs "based upon the fact that the gap between the rich and the poor, the north and the south, has not been abridged").

54 For example, in the mid-1970s, the DCs turned their attention to strengthening trade cooperation among themselves. See Gosovic, supra note 29, at $153-58$.

55 See Punta del Este Ministerial Declaration, supra note I, at 20, 23-24.

56 Id. at 20 .

57 See id. at $23-24$.

58 See Joseph F. Francois, Bradley McDonald, \& Hakan Nordstrom, Assessing the Uruguay Round 6 (Jan. 26-27, 1995) (unpublished manuscript presented to the World Bank Conference on the Uruguay Round and the Developing Economies, on file with the Harvard Law School Library).

59 See supra note 3; see also RoBERT E. Hudec, Enforcing InTERNATIONAL TRADE LAW 326 (I99I) (noting that, "[a]lthough the GATT agreement does apply to agricultural trade, special rules for agriculture permit substantial deviations from basic GATT policy, and even these permissive rules have been flouted by most members from the outset").

60 See supra note 3 . 
centerpiece of this effort.61 Some commentators have spied in the WTO a "judicialization" that contributes to the steady accumulation of legal process in international trade.62 For these commentators, the Uruguay Round represents the latest attempt to overcome weaknesses in international trade law and thereby advances it along the slow but inexorable path toward global government. ${ }^{63}$

\section{B. A Cynical Viere of the "Legality" of the GATT and UNCTAD}

Together, the GATT and UNCTAD arguably created substantial access for DCs to ICs' markets and therefore presumably helped increase DCs' exports. At the same time, however, these regimes often exacerbated or at least failed to improve DCs' trade imbalances. And although the prevailing multilateral trade regimes may not have caused DCs' economic dependence, they have not lessened it. A cynical view ${ }^{64}$ might attribute these failures to trade rules that seemed in their scope, the provisions for their enforcement, and their actual enforcement - not to reform, but only to reinforce the North-South economic hierarchy.

I. Legal Rules of the GATT. - ICs have consistently created rules that affronted the principles upon which they had purported to establish the GATT. First, even amidst the GATT's original declarations of principle and accompanying rules, the ICs fashioned for themselves several exceptions to address domestic concerns. Most notable from the DCs' perspective, the United States prevented the GATT from addressing agriculture and textiles, so that it could maintain subsidies and other protectionist measures for U.S. industry. ${ }^{65}$ Because $\mathrm{DCs}^{\prime}$ comparative advantage lay overwhelmingly in these goods, their omission from the GATT severely attenuated the trade benefits the agreement could confer upon DCs. ${ }^{66}$ The GATT also included an escape

61 See WTO Agreement, supra note 3 , at $\mathrm{Xr}_{44-52}$ (describing the WTO's administrative and enforcement structures and operation). Unlike those of its predecessors, decisions of the WTO dispute resolution panel remain binding upon the losing party even if the party objects, so that losing parties cannot legally "block" panel decisions as they could previously. See William D. Hunter, WTO Dispute Settlement in Antidumping and Countervailing Duty Cases, in THE CoMMERCE Department Speaks on International Trade and InVESTMENT 1994, at 547, 549 (PLI Corporate Law and Practice Course Handbook Series No. 863, 1994).

62 See, e.g., What's Needed for the GATT After the Uruguay Round?, 86 Proc. AM. Soc'y INT'L L. 69, 72 (I992) (remarks of Cristoph Bail).

63 See supra p. I715.

64 The cynical view contends that, because no international coercive authority exists to bind states, power relations shape state interaction. This view is rooted in positivism of the kind espoused by John Austin. See John Austin, The Province of Jurisprudence Determined 3, 6-8, 199 (London, John Murray 1832). Positivism informed the development of contemporary realism. For helpful examples of realism, see the essays compiled in The Relevance of INTERNATIONAL LAW, cited above in note 9.

65 See HuDEc, supra note 16, at 16.

66 See Programme of Action Proposed By Less-Developed Countries, annexed to Report of Committee III on Meetings of October/November Ig62, GATT Doc. L/1925 (Nov. 16, 1962), in 
clause that allowed governments to determine unilaterally when "unforeseen developments . . . cause[d] or threaten[ed] serious injury to domestic producers" and to withdraw temporarily from their GATT obligations. ${ }^{67}$ Although the GATT's Article XVIII also incorporated $\mathrm{DCs}^{2}$ request for an allowance to withdraw temporarily in order to promote domestic economic development, ${ }^{68}$ Article XVII, unlike the escape clause, required the withdrawing country to gain explicit GATT approval through an elaborate procedure. ${ }^{69}$

In addition, although the GSP arguably constitutes a principled elaboration on, rather than an unprincipled departure from, the ideal of free trade, ${ }^{70}$ its substantive coherence is compromised - like that

General Agreement on Tariffs and Trade, Basic Instruments and Selected DocuMENTS I88 annex at 204-06 (IIth Supp. I963) (noting the failure of GATT to liberalize trade in tropical products and proposing a plan to do so).

In the case of textiles, the United States and other ICs went so far as to create separate agreements culminating in the Multifiber Arrangement (MFA), formally known as the Arrangement Regarding International Trade in Textiles, Dec. 20, 1973, 25 U.S.T. 1001, T.I.A.S. No. 7840, extended by Protocol Extending the Arrangement Regarding International Trade in Textiles, GATT Doc. L/6030 (July 31, 1986), in General Agreement on TARIFfs AND Trade, Basic INSTRUMENTS AND SELECTED DOCUMENTS 7 (33d Supp. r987). The MFA "flagrantly violate[s]" GATT rules by protecting the ICs' textile industries. Henry R. Zheng, Defining Relationships and Resolving Conficts Between Interrelated Multinational Trade Agreements: The Experience of the MFA and the GATT, 25 STAN. J. INT'L L. 45, 5 I (1988).

67 GATT, supra note 2, art. XIX, II, 6I Stat. at A58, 55 U.N.T.S. at 258.

68 See id. art. XVIII, I I, 6I Stat. at A53, 55 U.N.T.S. at 252. Although the ITO had granted a number of such measures, the ICs participating in the original GATT negotiations demonstrated considerable reluctance to do the same. See HUDEc, supra note 16, at 14.

69 See GATT, supra note 2, art. XVIII, 6I Stat. at A53-A58, 55 U.N.T.S. at 252-58.

70 Many commentators have argued that the GSP forms a clear and profound departure from GATT principles. See, e.g., Ernst-Ulrich Petersmann, Economic, Legal and Political Functions of the Principle of Nondiscrimination, 9 WORLD ECON. II3, Ir3-2I (1986). However, the GSP arguably seeks not to detract from, but rather to fulfill the vision of global free trade. See Robert E. Hudec, Tiger, Tiger in the House: A Critical Appraisal of the Case Against Discriminatory Trade Measures, in 5 The New GatT Round of Multilateral Trade Negotiations 165, 203 (Ernst-Ulrich Petersmann \& Meinhard Hilf eds., I988) (noting this argument and the widespread diplomatic support for it); $c f$. Thomas M. Franck, Legitimacy in the Intemational System, 82 AM. J. INT'L L. 705, 750 (I988) (arguing that the apparent contradiction of the GSP "is redeemed" because it is both "consistent with the real intent of the specific rule and connect[ed] with that skein of principles integrating various other rules of the international system").

In the first place, the GSP displaces not the liberal economic concept of comparative advantage, but rather the mercantilistic concept that granting other nations unfettered access to domestic markets harms the granting nation. See, e.g., THE HISTORY OF UNCTAD, supra note 32 , at 107; TOWARDS A NEW TRADE Policy, supra note 24, at 28-31. Preferences maximize DC comparative advantages and therefore accelerate their economic growth, bringing ever closer a mutually prosperous trade environment. See id. The GSP "graduation" requirement, which requires $\mathrm{DCs}$ to relinquish preferences as they progress economically, confirms this understanding. See Differential and More Favourable Treatment: Reciprocity and Fuller Participation of Developing Countries, GATT Doc. L/4903 (Nov. 28, I979), in GENERAL AgreEMENT ON TARIFFs AND Trade, Basic Instruments AND Selected Documents 203, 203-05 (26th Supp. 1980). Moreover, the GSP furthers the GATT's commitment to equitable trade, described above in note 20 and accompanying text, under the theory that developing economies cannot effectively compete on the same terms as industrialized economies. Thus, the GSP differs from the exceptions and quali- 
of the original GATT agreement - by exceptions and qualifications designed to protect Northern interests. For example, unlike MFN concessions, which legally bind the contracting parties, a decision to extend a preference under the GSP is unilateral and non-binding. ${ }^{71}$ This discretionary quality also characterizes decisions on the range and quantity of products covered by the preferences. ${ }^{72}$ As a result, preferences vary widely among ICs, and within each IC are often limited to industries in which there is no substantial domestic stake, or in which the DCs do not have a significant comparative advantage. ${ }^{73}$ Additionally, ICs, especially the United States, often condition preferences on political requirements. ${ }^{74}$ Finally, the fact that preferences, again unlike MFN concessions, must be periodically renewed ${ }^{75}$ places even the attenuated benefits DCs receive from the GSP in continual jeopardy. The combination of these difficulties limits the GSP's capacity to increase most DCs' access to ICs' markets. ${ }^{76}$

The GSP provides evidence that ICs manipulate trade rules - especially those initiated by DCs - to evade the rules' intended effects. The ICs' introduction of "codes," or free-standing agreements, during the Tokyo Round constituted a similar effort to circumvent DCs' de-

fications ICs devised for themselves at the founding of the GATT, which are accompanied by no principled explanation. See, e.g., Olivier LoNG, LAW AND ITS LIMITATIONS IN THE GATT MULTILATERAL TrADE SYSTEM 69.(I985) ("Agriculture is treated differently in GATT for reasons that have nothing to do with the law but which are dictated by domestic political constraints.").

71 See Hudec, supra note 16, at 64; Ronald I. Meltzer, The U.S. Renewal of the GSP: Implications for North-South Trade, 20 J. WORLD TRADE L. 507, 508-09 (I986); Tamotsu Takase, The Role of Concessions in the GATT Trading System and Their Implications for Developing Countries, 21 J. WORLD TRADE L. 67, 75 (I987).

72 See Mordechai E. Kreinin \& J.M. Finger, A Critical Survey of the New International Economic Order, Io J. WorLd Trade L. 493, 496-97 (1976); Takase, supra note 71, at 76-77. ICs also used complex rules of origin to limit the range of products eligible for GSP concessions. See Kreinin \& Finger, supra, at 496.

73 See SPERO, supra note 16 , at $2 \pi \mathrm{r}$.

74 See Roshani M. Gunewardene, GATT and the Developing World: Is a New Principle of Trade Liberalization Needed?, I5 MD. J. INT'L L. \& TRADE 45, 50 (I991).

75 See SPERO, supra note 16 , at 211.

76 See Brown, supra note 6, at 362-63. GSP benefits were further eroded by across-the-board tariff reductions resulting from the GATT Tokyo Round negotiations. See Bela Balassa, The Tokyo Round and the Developing Countries, I4 J. WORLD TRADE L. 93, 98 (I980).

GATT negotiations for MFN concessions have similarly been characterized by ICs' manipulation. DCs sought to include industries in which they were interested, and do away with such "glaring" obstructions to free international trade as the Multifiber Arrangement. See Brown, supra note 6, at 365-68; supra note 66 (discussing the MFA); see also P.S. Sahai, Textile Trade and MFA IV: A Comment, Ig LAW \& PoL'y INT'L Bus. 223, 224-25 (1987) (expressing disappointment at the failure of MFA IV to live up to its objective of liberalizing textile trade). ICs, however, largely ignored $\mathrm{DCs}$ ' demands because of the quid pro quo nature of MFN negotiations. ICs asked DCs for few concessions, so DCs had little bargaining power to demand concessions. See HudEc, supra note 16, at 62; Kreinin \& Finger, supra note 72, at 495 . 
mands. ${ }^{77}$ Under the original GATT agreement, any amendment or addition required a formal two-thirds majority and, more often than not, a practical consensus. ${ }^{78}$ Because this structure encouraged the contracting parties to frame rules that were mutually satisfactory, it conferred a powerful bargaining tool upon DCs, who, as a majority of the GATT's contracting parties, could withhold their assent to a new rule until it was amended to address their concerns satisfactorily. If nothing more, this rule-making process forced ICs to listen to DCs' criticisms. As DCs warmed to the strategic possibilities of the GATT's original rule-making process, however, ICs ceased to initiate rule proposals under the conventional format and instead designed codes governing particular aspects of trade conduct. Because accession to a particular code was purely optional, ICs could create codes to their liking for trade among themselves without having to address $\mathrm{DCs}$ ' concerns. ${ }^{79}$

2. Authoritativeness of the GATT. - The GATT's vulnerability to the economically powerful nations allowed ICs to depart from GATT principles to serve their interests or evade DCs' demands. Not infrequently, this dynamic resulted in manipulation not only of the rules themselves, but also of the degree to which violations of the rules resulted in sanction. For example, the ICs originally conceived the GATT as a highly legalistic institution. ${ }^{80}$ The vast majority of enforcement proceedings in these early years were directed against DCs. ${ }^{81}$ By the early r96os, however, the DCs had begun to use GATT enforcement procedures against ICs. ${ }^{82}$ The ICs reacted by announcing that the GATT worked more effectively as a pragmatic institution than as a legalistic one. ${ }^{83}$ Moreover, although DCs were most likely to

77 See HUDEC, supra note 16, at 85-90; see also Kele Onyejekwe, GATT, Agriculture and Developing Countries, I7 HAMLINE L. REv. 77, $112-16$ (1993) (criticizing the Tokyo Round's Subsidies Code from the perspective of DCs).

78 See HuDEc, supra note 16 , at $8 \mathrm{I}$.

79 See id. at 8I-90 (describing initiatives to draft GATT codes on dumping, government procurement, and subsidies so as to circumvent DCs' demands and more closely reflect IC goals).

80 See Kenneth W. Dam, The GatT: Law and International Economic OrganizaTION 5 (1970) (criticizing this conception as a "naive view of law").

81 See Gunewardene, supra note 74, at 46. In many of these proceedings, DCs requested temporary release from their tariff obligations, under Article XVIII, to promote domestic economic development. See, e.g., Releases Granted to Ceylon (Nov. 28, 1957), in GeNeral AGReEMENT ON TARIFFS AND TRADE, BASIC INSTRUMENTS AND SELECTEd DOCUMENTS 14, 14-17 (6th Supp. 1958).

82 For example, in I96I, Uruguay instituted a claim with the GATT alleging that 15 ICs had committed 576 violations of GATT rules. See HUDEC, supra note 16, at 46-47.

83 See id. at 65 (describing the "pragmatist era" as "primarily a developed-country reflex"). GATT dispute resolution is representative of the progressionist-realist tension in international trade law. For example, most commentators view the GATT dispute resolution process as complex and indeterminate. See Gareth S.G. Grainger, GATT Disputes 12 (1989); ERIVIN P. Eichmann, Procedural Aspects of GATT Dispute Settlement: Moving Towards Legal ISM 2 (Stanford Center on Conflict and Negotiation, Working Paper No. I4, 1970). However, 
respond satisfactorily to findings that they had violated the GATT, they were the least likely to gain satisfactory outcomes to complaints that they had lodged against other countries for violations - even when the GATT dispute resolution system upheld those complaints. ${ }^{84}$

3. Legal Rules of UNCTAD. - As a structure of principles and rules, UNCTAD is more coherent than the GATT, because it arose from a clearer conception of international economic dynamics and a clearer normative vision. In some ways, however, this normative clarity posed the most serious obstacle to UNCTAD's implementation. DCs used UNCTAD to establish principles that were intended to compete with (or at least give the impression of competing with) those of the GATT. Because of the fear that ICs would summarily ignore rules that too directly challenged their interests, however, those principles often resulted in only relatively mild concrete reforms. Even as they convened the first Conference - a bold, historic occasion by all accounts - the DCs understood that any rules resulting from UNCTAD would have to incorporate an understanding of the ICs' limited tolerance.

For example, the first Conference on Trade and Development featured several proposals for the establishment of an alternative trading organization to the GATT. ${ }^{85}$ Despite the legal capacity of the Conference to follow this route, however, DCs declined to press it to do so. The ICs strongly opposed any duplication of or rivalry with the GATT, and the DCs anticipated that ICs would most likely refuse to join any such organization. ${ }^{86}$ Because the DCs depended on the ICs for the bulk of their export earnings, the proposals were effectively rendered implausible.

The DCs opted instead to formulate a set of guidelines, to be promoted and administered by UNCTAD, for the reform of international

whereas some view the process as slowly "moving toward legalism," $i d$. at 1 , others opine that the process will continue to be characterized by political "abuse," see GraINGER, supra, at 59.

84 For example, although Uruguay's claims mentioned above in note 82 helped to galvanize the DCs as a political group and to catalyze discussions of economic development, the dispute resolution panel resolved the dispute with minimal sanctions against the developed nations. See HUDEC, supra note 16, at 47-48. More generally, a comprehensive survey of GATT complaint outcomes found, for example, that the United States has "by far the worst compliance record." HUDEC, supra note 59, at 310 . In addition, although the United States was the least likely to respond satisfactorily to a GATT panel finding a violation, see $i d$. at 326 , it was the most successful in attaining fully satisfactory results against other countries when it lodged complaints, see id. at 323. By contrast, DCs were among the most likely to respond satisfactorily to GATT findings against them but were among the least likely to obtain satisfactory outcomes to complaints they lodged, even when those complaints were resolved in their favor. See $i d$. at 322-23. This dynamic was even more pronounced with respect to agricultural trade, the DCs' primary source of export earnings. See id. at 347 .

85 See Gosovic, supra note 29 , at 38-39.

86 See id. 
economic relations. ${ }^{87}$ Still, the DCs were faced with a decision about the degree to which those guidelines would be legally binding. Again, the ICs resisted, arguing that UNCTAD could legitimately function only in an advisory capacity. ${ }^{88}$ Ultimately, UNCTAD demanded "binding" commitments only to the general principles shaping the "New International Economic Order." UNCTAD articulated more concrete proposals only as goals, toward which it urged its members to work but that it was powerless to enforce.

4. Authoritativeness of UNCTAD. - Having succeeded in constraining UNCTAD's substantive legal authority, the ICs then pressured UNCTAD to minimize its already narrow enforcement capacity. Thus, the only enforcement mechanism with which DCs endowed UNCTAD was a mandate to survey and report the degree to which member nations had implemented its guidelines.89 $\mathrm{ICs}$, however, discouraged specific reports on their implementation of trade reforms suggested by UNCTAD. Pressure from the ICs succeeded in transforming these reports into general surveys of trends in international trade and development rather than pointed criticism. ${ }^{90}$

Viewing the Uruguay Round in light of this cynical history of the GATT and UNCTAD casts doubt on its capacity to improve DCs' positions in international trade by rationalizing the GATT rule structure. To begin with, it is not clear how the new rules, on their face, will affect DCs. For example, ICs argue that forcing DCs to lower their protectionist barriers and requiring more reciprocity will be trade-enhancing; DCs fear that doing so will erode their trade preferences and further reduce their chances of attaining economic development through export-led growth. ${ }^{91}$

A more important question than how the DCs will fare in the system the Uruguay Round designed on paper, however, may be how they will fare in the system that actually results. Already, several

87 UNCTAD's actual institutional mandate - the cryptically worded result of inveterate struggle between DCs and ICs - is extremely ambiguous. For example, General Assembly Resolution 1995 (XIX) provides that the UNCTAD Board "shall keep under review and take appropriate action within its competence for the implementation of the recommendations, declarations, resolutions and other decisions of the Conference." Establishment of the United Nations Conference on Trade and Development as an Organ of the General Assembly, G.A. Res. 1995, U.N. GAOR, 19th Sess., Supp. No. 15, at I, 2, U.N. Doc. A/5815 (1974). For a more thorough discussion of UNCTAD's role, see Gosovic, cited above in note 29, at 218-39.

88 See Walter M. Kotsching, The United States as an Instrument of Economic and Social Development, in The Global PARTNership 16, 29 (Richard N. Gardner \& Max F. Millikan eds., I968).

89 See Gosovic, supra note 29 , at 221 .

90 See id. at 222-23.

91 See Raymond F. Hopkins, Developing Countries in the Uruguay Round: Bargaining Under Uncertainty and Inequality, in WORID AGRICULTURE AND THE GATT I43, 149 (William P. Avery ed., I993); if. Balassa, supra note 76, at 98 (1980) (noting that the extensive across-the-board tariff reductions of the Tokyo Round would erode preferences for DCs' products under GSP). 
signs suggest that the Uruguay Round is vulnerable to the same problems that plague existing international trade law. For example, during the ratification proceedings in the U.S. Congress, the House Ways and Means Committee issued a report assuring that the Uruguay Round would not affect provisions in U.S. trade law that protect agricultural and textile industries. ${ }^{92}$

Moreover, familiar problems of legal authority and corresponding enforcement lurk behind the WTO. ICs, especially the United States, have demonstrated some reluctance to submit to the WTO's jurisdiction. For example, the United States fully intends to retain the use of Section 301 of the Trade Act of $1974,{ }^{93}$ a provision that has attracted considerable controversy from its inception, because it allows the United States unilaterally to adjudicate alleged violations and take action (in the form of retaliation) against asserted violators. ${ }^{94}$ In addition, the United States has essentially revealed an intention to retain disproportionate influence over the multilateral dispute resolution process. ${ }^{95}$ Altogether, the realist would likely conclude that these problematic aspects of the Uruguay Round's implementation, especially when assessed in the context of the history of multilateral trade agreements, do not bode well for the Round's promise of progress in international trade law.

\section{EMBracing THE Dichotomy AS AN EXPRESSION OF Competing Alternative Futures}

The foregoing Part demonstrates that international trade law can seem both trapped in an unending power play and slowly grinding toward a truer legality. Within conventional discourse on international legal theory, these interpretations compete in a struggle to displace each other and to lay superior claim to analytical validity. As such, they present an unsolvable quandary, because state actions always seem to implicate both progressionist and cynical views of international law. ${ }^{96}$ From this unending dualism, newer scholars have con-

92 See H.R. Rep. No. 826, I03d Cong., 2d Sess., pt. I, at 143-44, 150 (I994).

93 Trade Act of $1974 \S 301$, I9 U.S.C. \& 24 II (I988).

94 See, e.g., Fusae Nara, Note, A Shift Toward Protectionism Under Section 301 of the 1974 Trade Act: Problems of Unilateral Trade Retaliation Under International Law, Ig HoFSTRA I. REV. 229, 230-3I (I990).

95 See, e.g., H.R. REP. No. 826, supra note 92 , at 32 (advising that "the United States should foster policies and practices that ensure that ... the influence of the leading economies is not thwarted by countries that only participate marginally in the world economy, and [that] the United States is able to fully protect its economic interests and its sovereignty"); see also James Risen, New Trade Body's Power Called Overrated, L.A. Times, Dec. 2, 1994, at Ar8 (noting that, in response to WTO opponents' "cries 'of one-world government," an international trade expert in Washington responded, "Hey, if the Serbs can kick the United Nations around, then why should any American worry about the WTO?").

96 See Kennedy, supra note 9, at 362-64. 
cluded that these opposing views more or less "cancel each other."97 These scholars have sought to escape the "old, tired" dichotomy 98 by choosing to discard it, seeking instead alternative ways of conceptualizing international relations. ${ }^{99}$

As appealing as it may seem to dismiss utopia and realism as doomed to mutual cannibalization, however, these views still offer considerable insight into international law in general, and into international trade law in particular. With respect to explanatory power, the constant tension between these arguments, rather than rendering both empirically invalid, may mirror a tension in the real world. The history of international trade law strongly suggests that governments rely on both utopian and cynical views in their interactions with international legal structures. DCs, after all, must have been fully aware of the vulnerability of international legal structures to manipulation by economically powerful nations. Yet they may have consciously chosen to participate in these structures because, as relatively weak nations, they had no recourse in these fora save their claims as legally equal entities. It seems likely that they strategized half reliant on, and half wary of, the GATT and UNCTAD as independent legal authorities.

ICs, too, seemed to employ ambiguous conceptions of international trade law. While self-interest surely explains many of the inconsistencies and exceptions that riddle multilateral trade agreements and that

97 Koskenniemi, supra note $\mathrm{II}$, at 4, 8 (emphasis omitted).

98 Carty, supra note io, at 72.

99 For example, David Kennedy has argued for a reconceptualization of international legal discourse that focuses on the structure of arguments about international law to discover "how the process of setting words together could be both open to new combinations and yet comprehensible ... both open-ended and outcome-determinative." Kennedy, supra note 9, at 375. This "structuralist" approach examines the architecture of conventional discourse for clues about deeper dynamics in international legal thought, which might then be used to build new paradigms. For more on Kennedy's view of structuralism, see David Kennedy, Critical Theory, Structuralism and Contemporary Legal Scholarship, 21 NEw ENG. L. REV. 209 (1985-1986).

Kennedy applies this approach in examining the "contrast between the European Communities' 1992 program - seen as the completion of an internal market program [ $]$ " and "the continent's 'architectural' response to the fall of the Berlin Wall - understood as requiring new institutional and legal forms heralding a new century and a new order for international law." David Kennedy, Turning to Market Democracy: A Tale of Two Architectures, 32 HaRv. INT'L L.J. 373, 374 (199r). Kennedy argues that the movement toward placing Eastern and Central Europe in a "narrative" of international trade, as opposed to internal market integration, exiles that part of Europe to a "new third world," so that "there seems some danger that the East will arrive at the station marked 'market democracy' just after the train has departed for 'post-industrial society." Id. at $394-96$.

Other scholars have advocated approaches that similarly focus on the language of international legal discourse and its underlying philosophies. See, e.g., KoskEnNIEMI, supra note 9, at xvi-xxiv; Carty, supra note 10, at 67. These approaches search for new insights about international legal discourse through rigorous critique of the classical liberal philosophy and culture which, they argue, pervade both international legal agreements and the scholarship surrounding them. See KosKenNiEm, supra note 9, at xvi-xvii, 6; Anthony Carty, supra note 10, at 78-95; Anthony Carty, "Liberalism's Dangerous Supplements": Medieval Ghosts of International Law, I3 MrCH. J. INT'L L. 161, I6I (I99I) (book review). 
resulted largely from ICs' leadership of the international trade regime, other explanations seem also to carry at least partial weight. For example, ICs may simply have harbored good-faith disagreements on the proper contour of international trade rules. Alternatively, they may have pragmatically conceded to political pressures in particular contexts in order to keep the larger progressionist mission on course. Indeed, a sophisticated understanding of international trade law implicates all of these scenarios as multiple facets of the complicated business of drafting multilateral trade agreements.

Embracing the old dichotomy also may yield greater predictive accuracy in certain contexts. For example, the theoretical stalemate in conventional legal theory led New Stream scholars to predict that "policy makers for the greater powers" would dismiss "proponents" of the utopian viewpoint as "legalistic" and "irrelevant," and would lead the "lesser powers" "to lose faith" in international law. ${ }^{100}$ The Uruguay Round belies this prediction. Rather than losing faith and gravitating toward fewer legal restraints in international affairs, the contracting parties to the GATT have putatively stepped towards greater legalization and self-restraint. This apparent continuing vitality of legalism may lie in the fact that states, as actors in the international legal system, embrace both sides of the dichotomy. Thus, states may strive to create international legal constraints but may also willingly disregard those constraints. Neither side has conclusively flouted the other - but neither side has conclusively lost.101

With respect to trade and development in international economic law, therefore, it seems that scholars should consider retaining the old dichotomy, reconceptualized as a spectral expression of competing state strategies and competing futures in international law, as one of a host of alternative ways of viewing international legal discourse. Taking this step might allow for a more robust and intuitively satisfying explanation of international legal relations, and it might offer greater predictive and prescriptive capacities. The history of modern international trade suggests that both DCs and ICs have often moved between, and even simultaneously occupied, cynical and progressionist

100 Kennedy, supra note 9, at 389 .

101 A New Stream discourse that discards the traditional dichotomy may also obscure the workings of multilateral agreements in a way that might harm DCs. The New Stream tends to be fairly critical of the ICs' actions in the realm of international law, and much of New Stream scholarship constitutes an attempt to deconstruct the dominant discourse. Although such theoretical moves would seem to benefit DCs, they may actually distract from the need for effective development strategies. Like its domestic counterpart, the critical international legal theory of the New Stream seems to offer no clear directives for actors in the current legal system. See John Fellas, Reconstructing Law's Empire, 73 B.U. L. Rev. 715, 715 (1993); Ed Sparer, Fundamental Human Rights, Legal Entitlements, and the Social Struggle: A Friendly Critique of the Critical Legal Studies Movement, 36 STAN. L. REV. 509, 552-67 (1984). But see Mark G. Kelman, Trashing, 36 STAN. L. REv. 293, 297-329 (1984) (rebutting arguments that critical legal studies is neither concrete nor constructive). 
viewpoints of international law. Although the recent developments of the Uruguay Round indicate that multilateral trade agreements are moving toward greater determinacy and authority, therefore offering better prospects for reformist initiatives, a skeptical review of these agreements demonstrates that it is far too early to call the question on the apparent "legalization" of international trade.

Understanding international trade law in this way produces two conclusions. First, DCs should not discount the legal effectiveness of international trade agreements, but rather, should continue to push for their institutionalization and rationalization. Second, however, DCs should also recognize that the effectiveness of such reformist agitation may depend on the agitators' economic power independent of any international legal rule. DCs must, therefore, seek out strategies for attaining economic growth that do not depend solely on legal reform of the terms of trade between themselves and ICs.

The integration of regional markets presents a promising strategy in this regard. During the original GATT negotiations, European countries gained an exception for regional trade agreements; ${ }^{102}$ since then, the European Community has succeeded spectacularly in generating regional economic growth. ICs, given both their own history and their own current scramble toward regional integration, would be hard-pressed to locate viable objections, legal or political, to similar initiatives by DCs - and, over the years, several such initiatives have arisen. ${ }^{103}$ Regional integration among DCs stands a good chance of increasing their economic growth, which in turn, would almost certainly increase the bargaining power of the DCs in negotiating multilateral trade agreements. Moreover, in the event that the utopian vision of international law does not materialize, DCs will have protected themselves against an increasingly inward-looking international trade environment.

102 See GATT, supra note 2, art. XXIV, 6I Stat. at A66-A68, 55 U.N.T.S. at 268-73; see also DAM, supra note 80, at 275-95 (analyzing GATT provisions for regional arrangements).

103 Developing countries have undertaken numerous attempts at economic integration and have achieved varying levels of success. For a discussion of regional economic integration initiatives in Africa, Asia, and Latin America, see Colin L. McCarthy, Regional Integration of Developing Countries at Different Levels, 4 Transnat'l L. \& ConTEMP. Probs. 1, 1-7 (1994). See also C.A. Primo Braga \& Alexander J. Yeats, Minilateral and Managed Trade in the Post-Uruguay Round World, 3 MinN. J. GLOBAL TRADE 23I, 257-58 (I994) (listing I4 regional economic agreements). However, most of the DCs' regional integration efforts have been unsuccessful to date. Sec P. Kenneth Kiplagat, An Institutional and Structural Model for Successful Economic Integration in Developing Countries, 29 TEx. INT'L L.J. 39, 50 (1994). 